University of Montana

ScholarWorks at University of Montana

Numerical Terradynamic Simulation Group

Publications

Numerical Terradynamic Simulation Group

$5-1994$

\title{
Testing Forest-BGC Ecosystem Process Simulations Across a Climatic Gradient in Oregon
}

Steven W. Running

University of Montana - Missoula

Follow this and additional works at: https://scholarworks.umt.edu/ntsg_pubs

Let us know how access to this document benefits you.

\section{Recommended Citation}

Running, S. W. (1994), Testing Forest-BGC Ecosystem Process Simulations Across a Climatic Gradient in Oregon. Ecological Applications, 4: 238-247. doi:10.2307/1941930

This Article is brought to you for free and open access by the Numerical Terradynamic Simulation Group at ScholarWorks at University of Montana. It has been accepted for inclusion in Numerical Terradynamic Simulation Group Publications by an authorized administrator of ScholarWorks at University of Montana. For more information, please contact scholarworks@mso.umt.edu. 


\title{
TESTING FOREST-BGC ECOSYSTEM PROCESS SIMULATIONS ACROSS A CLIMATIC GRADIENT IN OREGON ${ }^{1}$
}

\author{
STEVEN W. RUNNING \\ School of Forestry, University of Montana, Missoula, Montana 59812 USA
}

\begin{abstract}
Field measurements from the Oregon Transect Ecological Research project (OTTER) were used to validate selected process simulations in the FOREST-BGC ecosystem model. Certain hydrologic, carbon, and nitrogen cycle process simulations were tested in this validation, either comparatively across sites, or seasonally at single sites. The range of simulated ecosystem-process rates across the OTTER sites was large; annual evapotranspiration (ET) ranged from 15 to $82 \mathrm{~cm}$, net photosynthesis (as carbon) from 2.2 to $22.8 \mathrm{Mg} / \mathrm{ha}$, and decomposition (as carbon) from 1.0 to $7.2 \mathrm{Mg} \cdot \mathrm{ha}^{-1} \cdot \mathrm{yr}^{-1}$. High correlations between predicted and measured data were found for: aboveground net primary production, $R^{2}=0.82 ; 100$-yr stem biomass, $R^{2}=0.79$; and average leaf nitrogen concentration, $R^{2}=0.88$. However, correlations for pre-dawn leaf water potential and equilibrium leaf area index (LAI) were much lower, because successful simulation of these variables requires accurate data for soil water-holding capacity. Defining the water-holding capacity of the rooting zone and the maximum surface conductance for photosynthesis and transpiration rates proved to be critical system variables that defied routine field measurement. Although many other processes are simulated in FOREST-BGC, no other processes had repeated field data sets for validations. Problems in parameterizing the model from disparate data sets are also evaluated, with suggestions for using ecosystem modeling in future integrated research programs.
\end{abstract}

Key words: carbon cycle; conifer forest; ecosystem model; ecosystem remote sensing; hydrologic cycle; leaf area index; model validation; net primary production; Oregon transect; OTTER project; stem biomass; transpiration.

\section{INIRODUCTION}

Simulation modeling is an essential tool for evaluating ecosystem activity at space and time scales beyond the limits of direct measurements ( $\mathrm{Agren}$ et al. 1991). Under the summary term "global change" a variety of physical, biological, and socio-economic changes are now taking place on the planet that will influence the biosphere in ways that can only be projected (Bonan 1991, Ojima 1992, Schimel et al. 1991). Even within current time frames, ecological questions are being asked requiring spatial analysis at landscape up to global scales for which we do not have any direct means of measurement (Schimel et al. 1991). As ecological modeling takes an increasingly prominent role as a research tool for space/time extrapolation, quality control is necessary for credibility (Burke et al. 1990). Ecological modeling is commonly criticized for lack of validation, yet it is practically impossible to validate complete models of systems as complex as an ecosystem. In order to simplify reality to an understandable level, each model begins with a set of assumptions that define the system structure, basic linkages, and constraints. This system design ultimately is limited only by the imagination of the modeler and may be a very

\footnotetext{
' Manuscript received 24 August 1992; revised 1 June 1993; accepted 14 June 1993.
}

abstract view of the system. (I sometimes think of the terrestrial biosphere as a chlorophyll sponge blanketing the earth with a thickness proportional to leaf area index (LAI) and only certain very general physiological properties.) However, validation of specific measurable components or computations should be possible for certain ranges of conditions and certain temporal and spatial scales, or the model is really only an intellectual toy.

Probably the most accepted form of model validation is to compare predicted model output directly to observed behavior. An objective of the OTTER project was this type of validation activity for the FOREST. BGC ecosystem model (Running and Coughlan 1988, Running and Gower 1991, Peterson and Waring 1994). Certain components of FOREST-BGC have previously undergone validation testing, including hydrologic cycle components (Knight et al. 1985, Nemani and Running 1989) and carbon cycle components (McLeod and Running 1988, Hunt et al. 1991, Korol et al. 1991).

Of the large suite of computations made by FOREST-BGC, only a handful have a direct analogue in normal ecological field measurements. These are:

Water: seasonal snowmelt rate, seasonal soil moisture depletion, seasonal leaf water potentials, and seasonal stream discharge;

Carbon: seasonal canopy $\mathrm{CO}_{2}$ and water flux rates, seasonal soil $\mathrm{CO}_{2}$ evolution, annual aboveground pri- 
mary production, leaf and stem, annual litterfall, equilibrium leaf area index, and stem biomass;

Nitrogen: annual mineralization, canopy $\mathrm{N}$ retranslocation, and litterfall $\mathrm{N}$.

Although the dual daily/yearly time resolution of FOREST-BGC matches the time dynamics of these measurements adequately, there are inherent mismatches in spatial scaling that are a consequence of the ecosystem structure defined by FOREST-BGC. FOREST-BGC is effectively a one-dimensional vertical flux model, which uses a default minimum 1-ha ground area definition. Horizontal heterogeneity is treated by classifying different cells across a landscape. Within a cell all site, stand, and climatic attributes are defined as homogeneous. Yet the instrumentation that produces many of these measurements provides at best a "point" sample representing only a few metres, and any areal sampling rapidly becomes difficult. Obtaining all of these measurements across the six OTTER study sites was well beyond the budget allocated. Alternatively, the model can be run for a single tree, if the ground occupancy of that tree can be accurately defined (Korol et al. 1991). For a fully occupied, even-aged stand, the area divided by the density is a good estimate, but for open, uneven-aged stands it is not.

Because of these constraints, this validation exercise will evaluate predicted and observed pre-dawn leaf water potentials as the primary hydrologic cycle variable; aboveground net primary production (ANPP), equilibrium LAI, and 100-yr stem biomass as carbon cycle variables; and leaf nitrogen concentration as a $\mathrm{N}$-cycle variable. The specific objective of this paper is to present the predicted vs. observed validation tests for selected variables on sites where measurements were made, either by the OTTER project or by other recent research across the transect. Additionally, I evaluate problems found in model parameterization and validation that may be valuable lessons for future ecosystem model implementations in large integrated research projects.

\section{METHODS}

A basic description of the OTTER study sites and the suite of measurements taken during the OTTER project are covered in Peterson and Waring (1994 [this issue]), Runyon et al. (1994 [this issue]), and Matson et al. (1994 [this issue]). I discuss only the details of the field measurements important to the modeling tests.

\section{Model parameterization}

In order to run the model for any area, a number of site, stand, and climatic data sets are required. Table 1 is an example of an input data file required for FOREST-BGC simulations. FOREST-BGC has default values for all critical parameters that have been derived and tested in other applications. If no data exist for a certain parameter, the model uses the default value. Often data exist but at the wrong scale. For example, instantaneous cuvette data for leaf conductances were available, but are not equivalent to the whole-canopy, daily average conductances needed.

By far the most difficult important parameter to define is soil water-holding capacity (SWC) available for water uptake by roots. Although typically these measurements are made for the top $1 \mathrm{~m}$ of soil, in reality we have no way of knowing the depth and rooting extension of trees on these sites. The SWC measured by accepted techniques (Table 1; see also Runyon et al. 1994) ranged from $4 \mathrm{~cm}$ to $22.6 \mathrm{~cm}$ across the sites, yet measured SWCs are clearly inadequate to support the observed vegetation. For example, assuming a modest transpiration rate of $3 \mathrm{~mm} / \mathrm{d}$ (well within observed rates for conifer forests, Waring and Schlesinger 1985), a SWC of $6.1 \mathrm{~cm}$ measured for the Corvallis (Oregon) site could provide transpiration for only 20 d without rain. Using the measured LAI of 5.6 for the Corvallis site, and observed climate files, soil water potential was simulated to be $<-6 \mathrm{MPa}$ on yearday 190, which caused full stomatal closure.

All surface water balance models, whether used in ecosystem models, hydrologic models, or even global circulation models (GCMs) must define in some way the system capacitance for soil water. SWC is the system hydrologic storage and directly determines how long transpiration can occur before physiological stress symptoms and dramatic shifts in Bowen ratios develop. Some current GCMs define a fixed 15 -cm soil water capacity for the entire world for lack of a dependable alternative (Avissar and Verstraete 1990, Meehl and Washington 1988). However, it is clear that typical soil-sampling data is the wrong methodology to rely on for this parameterization. The known seasonal development and timing of pre-dawn leaf water potentials, analogues for canopy water stress, may allow us to infer SWC better than the clearly erroneous field data.

I finally was forced to use the default SWC of 22.6 $\mathrm{cm}$ for all sites that we have used successfully for numerous previous applications with coniferous forests. I could have estimated SWC for each site by simulation, but that would have disallowed my validations of leaf water potentials and equilibrium leaf area index (LAI), two variables used in a hydrologic equilibrium logic for SWC (Nemani and Running 1989).

Maximum canopy conductance (optimum environmental conditions), which controls the maximum transpiration and photosynthesis rates, is another critical ecosystem parameter. Two core projects within the International Geosphere-Biosphere Program-GCTE (Global Change and Terrestrial Ecosystems) and BAHC (Biological Aspects of the Hydrologic Cycle)-plan a major coordinated effort to develop general logic for estimating maximum conductance for global vegetation types. Yoder (1992) attempted to measure a maximum conductance for the Scio stand with a field $\mathrm{CO}_{2}$ chamber; however the multiple environmental factors 
TABLE 1. A sample input data file (for the Corvallis, Oregon, site) required for the OTTER FOREST-BGC simulations. LAI $=$ leaf area index. All temperatures are in ${ }^{\circ} \mathrm{C}$.

\begin{tabular}{|c|c|c|c|}
\hline Value & Code & Name & Units \\
\hline \multicolumn{4}{|c|}{ State variables } \\
\hline 0.0 & $\mathrm{X}(1)$ & Snowpack & $\left(\mathrm{m}^{3}\right)$ \\
\hline 2260.0 & $\mathrm{X}(2)$ & Soil water content & $\left(\mathrm{m}^{3}\right)$ \\
\hline 0.0 & $X(3)$ & Water outflow & $\left(\mathrm{m}^{3}\right)$ \\
\hline 0.0 & $X(4)$ & Transpiration & $\left(\mathrm{m}^{3}\right)$ \\
\hline 0.0 & $\mathrm{X}(5)$ & Evaporation & $\left(\mathrm{m}^{3}\right)$ \\
\hline 0.0 & $X(6)$ & Photosynthesis (PSN) & $(\mathrm{kg})$ \\
\hline 0.0 & $\mathrm{X}(7)$ & Respiration, autotrophic & $(\mathrm{kg})$ \\
\hline $4.60 \times 10^{3}$ & $\mathrm{X}(8)$ & Leaf carbon & $(\mathrm{kg})$ \\
\hline $207.0 \times 10^{3}$ & $X(9)$ & Stem carbon & (kg) \\
\hline $4.60 \times 10^{3}$ & $X(10)$ & Root carbon & (kg) \\
\hline $23.0 \times 10^{3}$ & $X(11)$ & Leaf and root litter carbon & $(\mathrm{kg})$ \\
\hline 000 & $X(12)$ & Respiration, heterotrophic & (kg) \\
\hline $146.0 \times 10^{3}$ & $X(13)$ & Soil carbon & $(\mathrm{kg})$ \\
\hline 50.0 & $X(14)$ & Available nitrogen & (kg) \\
\hline 69.0 & $X(15)$ & Leaf nitrogen & (kg) \\
\hline 207 & $X(16)$ & Stem nitrogen & (kg) \\
\hline 34.0 & $X(17)$ & Root nitrogen & (kg) \\
\hline 460.0 & $X(18)$ & Leaf + Root litter nitrogen & (kg) \\
\hline 7695 & $X(19)$ & Soil nitrogen & (kg) \\
\hline 000 & $X(20)$ & Nitrogen loss & $(\mathrm{kg})$ \\
\hline \multicolumn{4}{|c|}{ Constant parameters } \\
\hline 25.0 & $\mathrm{~B}(1)$ & Specific leaf area & $\left(\mathrm{m}^{2} / \mathrm{kg} \mathrm{C}\right)$ \\
\hline-0.5 & $\mathrm{~B}(2)$ & Canopy light extinction coefficient & (unitless) \\
\hline 2260.0 & $B(3)$ & Soil water capacity & $\left(\mathrm{m}^{3}\right)$ \\
\hline 0.0005 & B(4) & Canopy water interception coefficient & $\left(m \cdot[L A I]^{-1} \cdot d^{-1}\right)$ \\
\hline $1.0 \times 10^{4}$ & $\mathrm{~B}(5)$ & Ground surface area & $\left(\mathrm{m}^{2} / \mathrm{ha}\right)$ \\
\hline 0.0007 & $B(6)$ & Snowmelt coefficient & $\left(m \cdot{ }^{\circ} \mathrm{C}^{-1} \cdot \mathrm{d}^{-1}\right)$ \\
\hline 44.0 & $\mathrm{~B}(7)$ & Latitude & (degrees) \\
\hline 0.8 & $\mathrm{~B}(8)$ & 1 - Surface albedo & (unitless) \\
\hline 0.5 & B(9) & Spring minimum leaf water potential & (MPa) \\
\hline 3000 & $\mathrm{~B}(10)$ & Leaf conductance radiation threshold & $\left(\mathrm{kJ} \cdot \mathrm{m}^{-2} \cdot \mathrm{d}^{-1}\right)$ \\
\hline 0.0010 & $\mathrm{~B}(11)$ & Maximum canopy leaf conductance & $(\mathrm{m} / \mathrm{s})$ \\
\hline 2.0 & $\mathrm{~B}(12)$ & Leaf water potential at stomatal closure & $(\mathrm{MPa})$ \\
\hline 0.05 & $\mathrm{~B}(13)$ & Leaf conductance humidity reduction & $\left(\mathrm{m} \cdot \mathrm{s}^{-1} \cdot \mu \mathrm{m}^{-1} \cdot \mathrm{cm}^{-3}\right)$ \\
\hline 432 & $B(14)$ & Photosynthesis light compensation point & $\left(\mathbf{k} J \cdot \mathrm{m}^{-2} \cdot \mathrm{d}^{-1}\right)$ \\
\hline 9720 & $\mathrm{~B}(15)$ & Photosynthesis response coefficient & $\left(\mathrm{kJ} \cdot \mathrm{m}^{-2} \cdot \mathrm{d}^{-1}\right)$ \\
\hline 0.0008 & $\mathrm{~B}(16)$ & Maximum leaf $\mathrm{CO}_{2}$ conductance & $(\mathrm{m} / \mathrm{s})$ \\
\hline 0 & $\mathrm{~B}(17)$ & Minimum photosynthesis temperature & $\left({ }^{\circ} \mathrm{C}\right)$ \\
\hline 40 & $B(18)$ & Maximum photosynthesis temperature & $\left({ }^{\circ} \mathrm{C}\right)$ \\
\hline 0.00015 & $\mathrm{~B}(19)$ & Leaf respiration coefficient & $\left(\mathrm{kg} \cdot \mathrm{kg}^{-1 \cdot{ }^{\circ}} \mathrm{C}^{-1} \cdot \mathrm{d}^{-1}\right)$ \\
\hline 0.0020 & $\mathrm{~B}(20)$ & Stem respiration coefficient & $\left(\mathrm{kg} \cdot \mathrm{kg}^{-1 \cdot} \cdot{ }^{\circ} \mathrm{C}^{-1} \cdot \mathrm{d}^{-1}\right)$ \\
\hline 0.0002 & $B(21)$ & Root respiration coefficient & $\left(\mathrm{kg} \cdot \mathrm{kg}^{\left.-1 \cdot{ }^{\circ} \mathrm{C}^{-1} \cdot \mathrm{d}^{-1}\right)}\right.$ \\
\hline 0 & $\mathbf{B}(22)$ & & \\
\hline 4.0 & $B(23)$ & Temperature coefficient, mesophyll conductance & $\left({ }^{\circ} \mathrm{C}\right)$ \\
\hline 0 & $\mathrm{~B}(24)$ & & \\
\hline 0.085 & $\mathrm{~B}(25)$ & $Q_{10}$ response coefficient for respiration & $\left({ }^{\circ} \mathrm{C}\right)$ \\
\hline 0.044 & $\mathrm{~B}(26)$ & Maximum leaf nitrogen concentration & $(\mathrm{kg} / \mathrm{kg}$ of $\mathrm{C})$ \\
\hline 0.0132 & $\mathrm{~B}(27)$ & Minimum leaf nitrogen concentration & $(\mathrm{kg} / \mathrm{kg}$ of $\mathrm{C})$ \\
\hline 0.50 & $\mathrm{~B}(28)$ & Leaf nitrogen retranslocation & (fraction/yr) \\
\hline 1.0 & B(29) & Soil water decomposition coefficient $\{0-1\}$ & (unitless) \\
\hline 0.5 & $\mathrm{~B}(30)$ & Nitrogen/carbon decomposition coefficient & (fraction) \\
\hline 20.0 & $\mathrm{~B}(31)$ & Maximum leaf area index & (unitless) \\
\hline 3.5 & $\mathrm{~B}(32)$ & Leaf turnover rate & (yr) \\
\hline 0.25 & $\mathrm{~B}(33)$ & Leaf lignin fraction & (fraction) \\
\hline 0 & $B(34)$ & & \\
\hline 1.0 & $\mathrm{~B}(35)$ & Leaf/root nitrogen availability & (unitless) \\
\hline 0 & $\mathrm{~B}(36)$ & Date of spring leaf growth & (yearday) \\
\hline 365 & $\mathrm{~B}(37)$ & Date of fall leaf drop & (yearday) \\
\hline 20.0 & $\mathrm{~B}(38)$ & Mobile nitrogen retention time & (yr) \\
\hline 5.0 & $\mathrm{~B}(39)$ & Atmospheric nitrogen deposition & $\left(\mathrm{kg} \cdot \mathrm{ha}^{-1} \cdot \mathrm{yr}^{-1}\right)$ \\
\hline 0.0 & $\mathrm{~B}(40)$ & Biological nitrogen fixation & $\left(\mathrm{kg} \cdot \mathrm{ha}^{-1} \cdot \mathrm{yr}^{-1}\right)$ \\
\hline 0.02 & $\mathrm{~B}(41)$ & Stem turnover coefficient & (fraction/yr) \\
\hline 0.80 & $\mathrm{~B}(42)$ & Root turnover coefficient & (fraction/yr) \\
\hline 0.35 & $\mathrm{~B}(43)$ & Leaf growth respiration & $(\mathrm{kg}$ of $\mathrm{C} / \mathrm{kg})$ \\
\hline 0.30 & $\mathrm{~B}(44)$ & Stem growth respiration & $(\mathrm{kg}$ of $\mathrm{C} / \mathrm{kg})$ \\
\hline 0.35 & $B(45)$ & Root growth respiration & $(\mathrm{kg}$ of $\mathrm{C} / \mathrm{kg})$ \\
\hline 50.0 & $B(46)$ & Decomposition temperature optimum & $\left({ }^{\circ} \mathrm{C}\right)$ \\
\hline 0.03 & $\mathrm{~B}(47)$ & Soil/litter carbon decomposition fraction & (unitless) \\
\hline 0.4 & $\mathrm{~B}(48)$ & Decomposition rate scalar & (unitless) \\
\hline
\end{tabular}


were never simultaneously "optimum" for a legitimate field measurement, and taking severed branches into controlled environment chambers also failed to produce consistent results.

Preliminary simulations with FOREST-BGC using the default canopy conductance of $0.0016 \mathrm{~m} / \mathrm{s}$ generated canopy water stress at the coastal Cascade Head (CASCHD) site when in reality none occurred, as is known from the leaf water potential data. Ryan (1991) also found that FOREST-BGC overestimates canopy conductance of larger mature trees, because the model parameters were initially developed from data on 2-8 m tall saplings. Knight et al. (1981) used whole tree potometers on Pinus contorta stands in Wyoming to estimate total canopy conductance. They found maximum conductance in June of $0.00167 \mathrm{~mm} / \mathrm{s}$ for saplings $6 \mathrm{~cm}$ in diameter, dropping to $0.0007 \mathrm{~mm} / \mathrm{s}$ for trees $18-22 \mathrm{~cm}$ in diameter. Consequently, 1 lowered the maximum canopy conductance for all sites from 0.0016 to $0.0010 \mathrm{~mm} / \mathrm{s}$. It has been hypothesized that increasing hydraulic flow resistances in larger, older trees produces canopy water stress unrelated to climate, a detail of physiology not incorporated into FORESTBGC (Hinckley and Ceulemans 1989).

An alternative possible cause for the problem of excess early-season water stress at the Corvallis site could have been that the maximum canopy conductance rate, $B(11)=0.0016 \mathrm{~mm} / \mathrm{s}$ used for all sites, was too high, by a factor of 3-4. However, a canopy conductance of $0.0004 \mathrm{~mm} / \mathrm{s}$ would result in maximum stand transpiration rates of $<1 \mathrm{~mm} / \mathrm{d}$, substantially less than the $3-5 \mathrm{~mm} / \mathrm{d}$ expected for a forest of $\mathrm{LAI}=5.6$ as measured from micrometeorologically based tower flux measures of evapotranspiration (ET) over forests (Baldocchi et al. 1988).

Clearly, the "top-down" whole-canopy estimates of transpiration and conductance produced by micrometeorological or potometer techniques provide an important check on whole-canopy estimates based on extrapolation of "bottoms up" cuvette data. By using these top-down constraints imposed by the biophysical system we can also derive critical yet problematic ecosystem parameters by simulation. Micrometeorological research has shown that, no matter what combination of climate, LAI, soil water, and canopy conductance, latent energy limitations allow maximum forest ET no greater than $\approx 6 \mathrm{~mm} / \mathrm{d}$ except for very special advective conditions (Waring and Schlesinger 1985). Using that limit, and known LAI and climate, the necessary range of soil water capacity and canopy conductance can be derived. If the soil water capacity defined is wrong, canopy water stress will be mistimed seasonally. Conversely if the canopy conductance is wrong, either the ET limit will be exceeded, or the trajectory of the drought magnitude will be wrong. This diagnostic relies on some type of accurate "drought monitor," which may be pre-dawn leaf water potentials on individual trees, tower water flux data or soil mois- ture depletion data for small stands, and possibly satellite monitoring for regions (Nemani et al. 1993).

On sites without a seasonal drought, derivation of these hydrologic parameters is much more difficult, and ultimately must rely on temporally imprecise streamflow data. Tuning the maximum canopy conductance with carbon cycle data is possible with integrated carbon variables, such as net primary production (NPP) or component biomass development. However, the carbon cycle is more complex than the hydrologic cycle at the stand level, involving photosynthesis-respiration balances, aboveground/belowground allocation, autotrophic and heterotrophic processes, etc. Tuning the canopy conductance with hydrologic variables, when appropriate, is less complex. Of course this implies a constant relationship between the maximum conductances of water vapor and $\mathrm{CO}_{2}$ (Jarvis 1981).

FOREST-BGC simulates ecosystem processes assuming no external perturbations. Two sites had recent perturbations that temporarily reduced the LAI to substantially below natural conditions-Santiam because of insect defoliation, and Metolius because of selective logging (Runyon et al. 1994 [this issue]). Consequently, to simulate natural stand biogeochemistry, I substituted LAI for these sites from Gholz (1982), changing Santiam from 1.9 to 4.3 , and Metolius from 0.7 to 3.0 , to provide the model with LAI appropriate for unperturbed $100-y r$ simulations. However, for validation simulations of daily processes such as photosynthesis or transpiration during the field period of the OTTER experiment, the current LAI was required.

Definition of the compartment sizes of stem, root, litter, and soil carbon and nitrogen is also needed for each site to initialize the model (Table 1). Because these data were not consistently taken for each OTTER site, an attempt was made to assemble the data from a combination of field measurements and published and unpublished data. The soil carbon and nitrogen compartments have rather long time constants of activity, much like the equivalent compartments in Century (Parton et al. 1987), so this mix of parameter sources had little influence on model stability. However, balanced definition of the litter and root compartments is important to model stability. Using a combination of direct measurements with literature values produced some nonsensical balances that destabilized the model. For example, a literature estimate of root nitrogen was initially combined with a field measurement of root carbon. The resulting root nitrogen concentration was six times larger than any reported in the literature. The preferred solution for this problem is to have a consistent, complete field data set collected for every site, which was beyond the OTTER budget.

Alternatively, I derived a set of allometric relationships between these variables based on certain assumptions, that then served as balanced default values for these compartment sizes. These assumptions were 
TABLE 2. Hydrologic and carbon balance components simulated for the OTTER sites for 1990 climate and current stand conditions.

\begin{tabular}{|c|c|c|c|c|c|c|}
\hline \multirow[b]{2}{*}{ Site } & \multirow{2}{*}{ Outflow } & \multicolumn{2}{|l|}{$\begin{array}{c}\text { Hydrologic } \\
\text { balance }(\mathrm{cm} / \mathrm{yr})\end{array}$} & \multirow{2}{*}{$\begin{array}{l}\text { Photosynthesis } \\
\text { (kg carbon) }\end{array}$} & \multicolumn{2}{|c|}{ 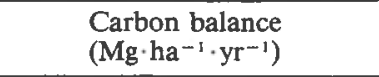 } \\
\hline & & Evaporation & Transpiration & & Respiration & Decomposition \\
\hline Cascade Head & 179 & 30 & 40 & 22.8 & 10.2 & 5.1 \\
\hline Alder & 211 & 15 & 24 & 16.0 & 1.4 & 3.3 \\
\hline Corvallis & 55 & 35 & 36 & 17.7 & 9.2 & 4.3 \\
\hline Scio & 63 & 40 & 42 & 22.7 & 8.5 & 6.0 \\
\hline Santiam & 55 & 34 & 26 & 12.4 & 5.1 & 7.2 \\
\hline Metolius & 38 & 11 & 8 & 3.4 & 0.7 & 1.0 \\
\hline Juniper & 42 & 9 & 6 & 2.2 & 0.6 & 1.4 \\
\hline
\end{tabular}

that: (1) fine root carbon equals leaf carbon (Vogt 1991, Nadelhoffer and Raich 1992); (2) leaf turnover averaged 4 yr (Gower and Richards 1990); (3) litter residence time $=10$ yr (Vogt et al. 1986, Prescott et al. 1989); (4) average litter $C: N=50$ (Prescott et al. 1989); (5) leaf nitrogen concentration $=1.5 \%$, and root nitrogen concentration is 0.5 of leaf nitrogen concentration (Vitousek et al. 1988). The resulting relationships then were derived, all based originally on leaf carbon, X(8) (see Table 1):

$$
\begin{aligned}
& \text { Root C, X(10) = Leaf C, X(8) } \\
& \text { Leaf }+ \text { Root Litter C, } X(11)=5 \times X(8) \\
& \text { Leaf } N, X(15)=0.015 \times X(8) \\
& \text { Root } N, X(17)=0.0075 \times X(8) \\
& \text { Leaf }+ \text { Root Litter } N, X(18)=0.1 \times X(8)
\end{aligned}
$$

I emphasize that these are only initial conditions; the model re-computes these variables annually throughout the simulations. This logic builds upon the principal of FOREST-BGC to derive as much of the ecosystem structure as possible from LAI, in order to allow use of remote sensing for regional extrapolations. This logic is similar to that used in Ryan (1991) to estimate gross carbon budgets for forests.

The only plant functional parameters changed for each site were $B(1)$, specific leaf area, and $B(32)$, leaf turnover rate. These structural parameters determine how much carbon will be required for annual canopy replacement and are subordinate only to the process rates of photosynthesis, respiration, and decomposition in control over the magnitude and rate of carbon cycling. All physiological variables were constant, effectively using "generic" tree physiological responses (Table 1).

Alder (Alnus rubra Nutt.) is a deciduous nitrogenfixing tree that is a common component of the Oregon coastal forests and a particular challenge for this model that was developed for western evergreen trees. To parameterize FOREST-BGC for the Alder site, leaf turnover was set to $1 \mathrm{yr}$, the leaf-on to leaf-off period defined as yearday $120-270$, the range of minimum to maximum leaf nitrogen concentrations was $1.2-4 \%$ dry mass, the maximum $\mathrm{LAI}=6$, and respiration coefficients (as carbon) changed as follows, leaf $=0.00060$, stem $=0.0040$, and root $=0.0006 \mathrm{~kg} \cdot \mathrm{kg}^{-1} \cdot{ }^{\circ} \mathrm{C}^{-1} \cdot \mathrm{d}^{-1}$ (see Table 1: $\mathrm{B}(19), \mathrm{B}(20), \mathrm{B}(21)$ for comparisons). A biological $\mathrm{N}$ fixation rate of $50 \mathrm{~kg} \cdot \mathrm{ha}^{-1} \cdot \mathrm{yr}^{-1}$ was also defined for Alder. FOREST-BGC defines the maximum canopy conductance partially from leaf nitrogen concentrations. The maximum canopy conductance (Table 1: $\mathrm{B}(11)$ ) remained at $0.0010 \mathrm{~m} / \mathrm{s}$ for alder; however, the high leaf $\mathrm{N} \%$ exhibited by the Alder site resulted in calculated maximum conductances of 0.0027 $\mathrm{m} / \mathrm{s}$, using the same physiological response equation as for the conifers (Running and Gower 1991). All other $B$ constants in Table 1 were left unchanged from the conifer values.

\section{Simulation runs}

After developing the initialization files as per Table 1 for each OTTER site, and re-formatting the 1990 daily meteorological data collected at each study site for model requirements, simulations were done. First a 1-yr simulation was done, with 5-d output of hydrologic and canopy process variables from the daily half of the model and the existing LAI estimates for Santiam and Metolius. These results were used to validate the "fast response" hydrologic and physiological process rates interannually across the six sites. Second, a 100-yr simulation was done, using the natural condition LAI for Santiam and Metolius, reusing the 1990 climate files for all $100 \mathrm{yr}$, and printing annual carbon and nitrogen cycle variables. These runs were done initiating the stem carbon at $10 \%$ of the current value to represent a young sapling stand just reaching maximum LAI and letting the model run for $100 \mathrm{yr}$. These results were used to evaluate time-integrating processes like stem biomass development, leaf area index equilibration, leaf nitrogen concentrations after the nitrogen cycle components have balanced, and decomposition rates after stabilization of soil carbon. The OTTER stands are not even-aged, so this approximate age of 100 yr produces a near-equilibrium stand condition. All other initial conditions were unchanged.

Predicted and observed data were compared for seasonal pre-dawn leaf water potentials at Corvallis and Metolius, annual aboveground NPP at all sites, equilibrium LAI at all sites, and equilibrium stem carbon at all sites. 

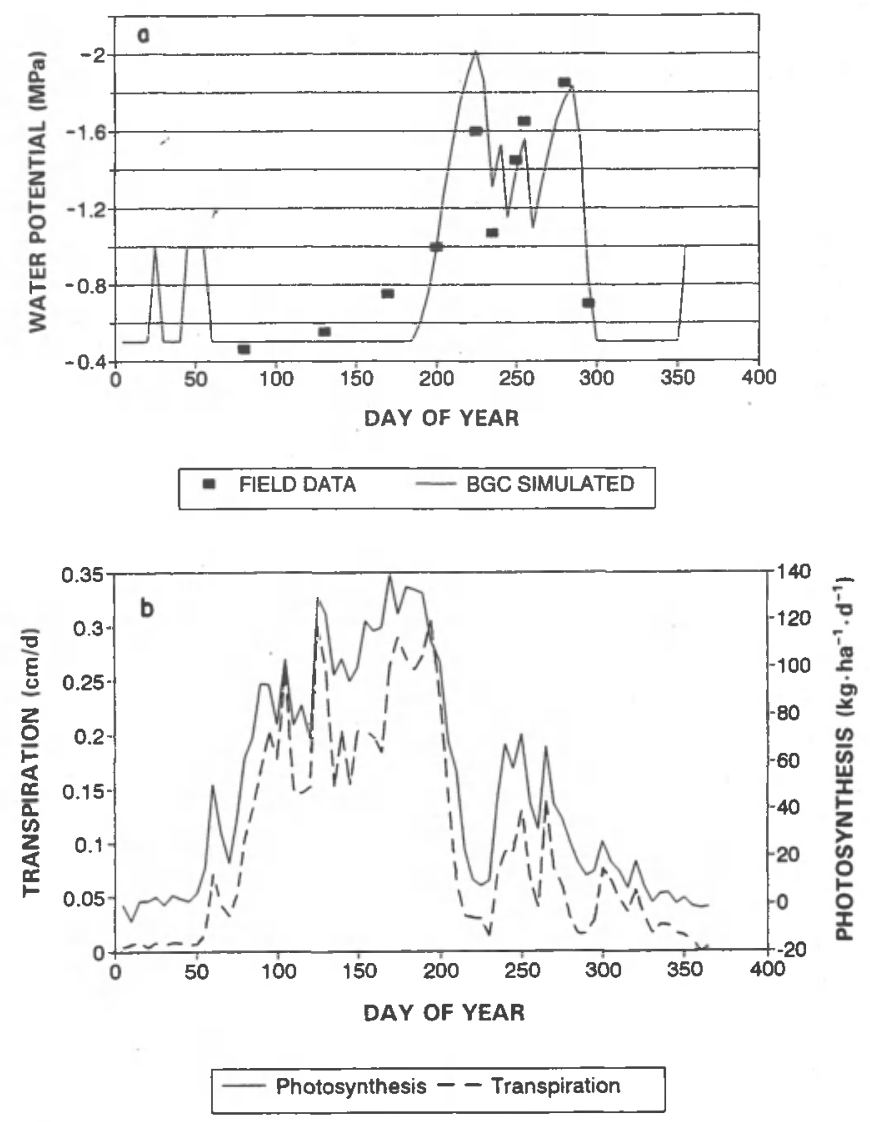

FIG. 1. Water relations and photosynthesis at the Corvallis, Oregon, site (Waring's Woods). (a) Predicted and observed (FOREST-BGC model) pre-dawn leaf water potentials for 1990. Field data are from Runyon et al. (1994 [this issue]). (b) Simulated seasonal canopy processes, illustrating the influence of seasonal drought on canopy process rates.

\section{RESULTS AND Discussion}

The tremendous range in ecological activity produced by the climatic gradient across Oregon is evident by the range of process rates simulated for these sites (Table 2). It is also critical to note that this range of process rates was simulated despite varying only climate, stand LAI, specific leaf area, and leaf turnover rate. No species-specific physiology was represented. For global-scale biome modeling it is essential to be able to represent physiology in a general way.

\section{Water balance}

Only the Corvallis and Metolius sites had a significant seasonal canopy water stress and repeated plant water stress measurements for 1990 . The predicted and observed seasonal trace of canopy water stress, and its influence on simulated photosynthesis and transpiration, are shown for Corvallis in Fig. 1. Both the timing and absolute magnitude of canopy water stress are well represented by the simulations, implying a good hydrologic balance calculation in the model-remarkable considering that soil water-holding capacity was defaulted for all sites at $22.6 \mathrm{~cm}$. The Metolius simulation was more difficult, because logging had reduced the LAI below natural conditions. In order to pre-condition the model for the simulated years, FOREST-BGC was simulated for $10 \mathrm{yr}$ with an initial low LAI of 1.0 (effectively a sapling-sized stand). At the end of this period, simulated LAI was 2.8 (compared to the 3.0 measured by Gholz 1982). The 1-yr simulation was started with this new LAI. Fig. 2 illustrates that, considering the "double simulation" of both LAI and hydrologic balance, predictions of maximum canopy wa-

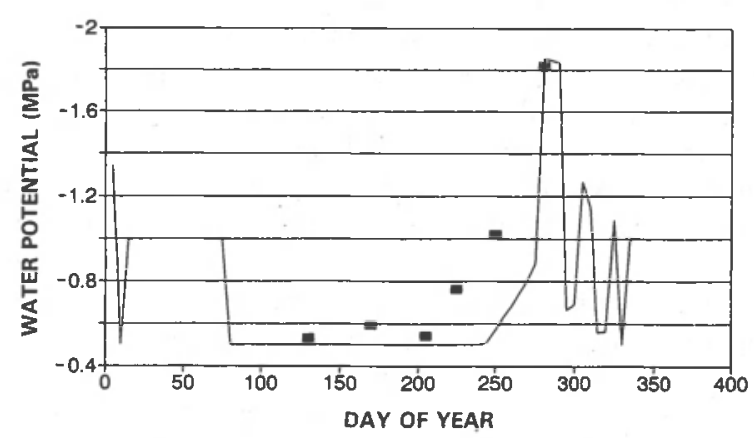

- FIELD DATA BGC SIMULATED

Fig. 2. Predicted and observed seasonal pre-dawn leaf water potentials for Metolius, 1990. Because the Metolius site was partially logged in 1989 , FOREST-BGC was first used to simulate the original LAI, then the seasonal simulation for 1990 was done to predict the observed plant water stress. 


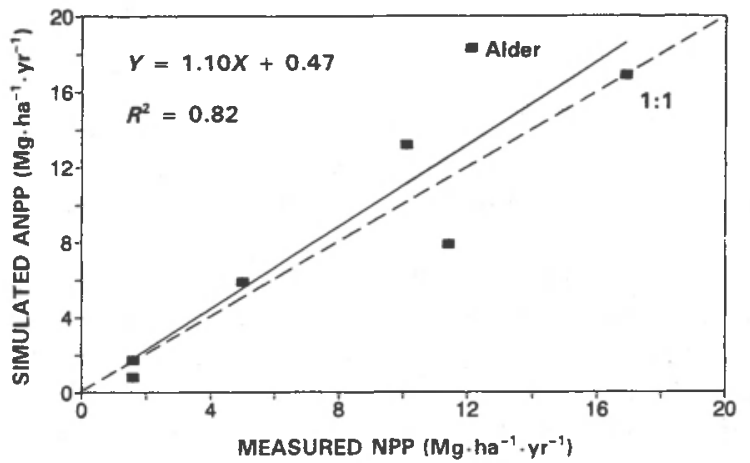

FIG. 3. FOREST-BGC validation for the seven OTTER sites: predicted and observed annual aboveground net primary production (ANPP). The two fertilization plots are excluded because treatments have not been produced long enough to reach a new equilibrium.

ter stress were good; however, seasonal timing of stress was delayed by $\approx 30 \mathrm{~d}$, again a result of having no sitespecific soil water-holding capacities (SWCs).

FOREST-BGC simulated a substantial seasonal canopy water stress at Scio, because of the high transpiration capacity produced by an LAI of 8.6 and using the default SWC of $22.6 \mathrm{~cm}$. Increasing the soil waterholding capacity to $50 \mathrm{~cm}$ (a reasonable value if rooting depth is $>2 \mathrm{~m}$ ), the model was able to reproduce the observed lack of canopy water stress at the Scio site. Either the trees have deep root systems, or microsite subsurface drainage at Scio must replenish soil water, because there is a long history of measuring seasonal summer drought in Oregon forests (Zobel et al. 1976), and normally a forest like Scio should experience measurable drought in late summer. This is a reminder that models like FOREST-BGC simulate average conditions, particularly when general default values are used for parameterization, but can only represent peculiar microsites with extensive site-specific data. New, comprehensive, regional ecosystem simulations now take into account lateral routing of soil water based on topographic and soil physical properties (Band et al. 1993).

The driest OTTER site, Juniper, also illustrated a limitation caused by model assumptions. The Juniper site has only partial vegetation cover, and a small overall LAI, 0.5 when averaged to the default 1-ha ground area. However, FOREST-BGC assumes that this LAI can tap the soil water supply of the entire hectare ground area. Consequently simulations produced no water stress, when in reality leaf water potentials of less than $-2.0 \mathrm{MPa}$ were reached. If FOREST-BGC were parameterized for a single juniper tree, and the LAI and ground surface area that it specifically occupied were defined, the simulation would have shown that a juniper tree with LAI of 3.5 would simulate the seasonal observed water stress of $-2.0 \mathrm{MPa}$. Alternatively, if a fractional vegetation cover of $\approx 15 \%$ of the 1 -ha ground surface area in FOREST-BGC were defined for the measured LAI of 0.5 , an effective LAI of 3.5 of the vegetated area would result. A new FOREST-BGC version that includes a second canopy layer competing for light and soil moisture, such as an understory grass, is near completion.

\section{, Carbon cycle simulations}

Aboveground net primary production (ANPP) was measured at all OTTER sites (Runyon et al. 1994 [this issue]), and was simulated by FOREST-BGC (Fig. 3). The only parameters varied among sites were the initial carbon and nitrogen compartments, critical for initiating multi-year simulations. The most conspicuous outlying point on this analysis was the alder stand at Cascade Head. Alder, being both a deciduous tree and a nitrogen fixer, presents the greatest challenge to the general physiology defined in FOREST-BGC. FOREST-BGC overpredicted the ANPP of the alder stand (18.3 Mg/ha simulated and $11.7 \mathrm{Mg} / \mathrm{ha}$ measured) because the model removed all nitrogen limitations, thus producing NPP limited only by incident radiation and air temperature on this wet coastal site. The most likely causes of these large errors are that either the model simulated respiration losses much too low, and/or root (and possibly $\mathrm{N}$-fixing symbionts) carbon allocation was too small. This simulation provided an important lesson to the limits of "generic physiology." Obviously the physiology of evergreen conifers is different enough from the deciduous alder that significant model adjustments were needed. The next question is whether a generic physiology for deciduous trees can be defined that accurately represents more species than alder alone.

Interestingly, the poor performance of the model simulating summer water stress at the Scio site had only a small effect on the year-long primary production simulation for that site, $16.0 \mathrm{Mg} / \mathrm{ha}$ simulated, and $17.5 \mathrm{Mg} / \mathrm{ha}$ measured. Although the timing and magnitude of peak water stress is the most rigorous test of the hydrologic balance simulation, the integrated time

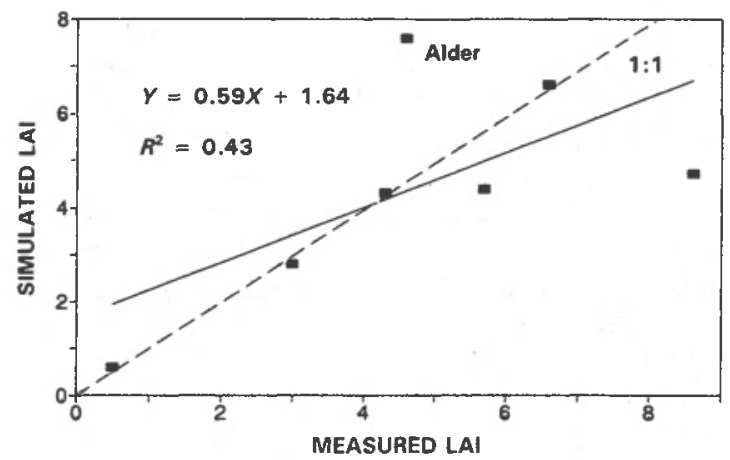

FIG. 4. FOREST-BGC validation for the seven OTTER sites: comparison of observed leaf area index (LAI) with predictions of the equilibrium LAI at the end of a $100-\mathrm{yr}$ simulation. Simulated LAI peaked around year 20 of the simulations, then stayed constant except for the Scio site, which peaked at $\mathrm{LAI}=6.5$, but at $100 \mathrm{yr}$ was reduced to 4.7 by nitrogen limitation. 


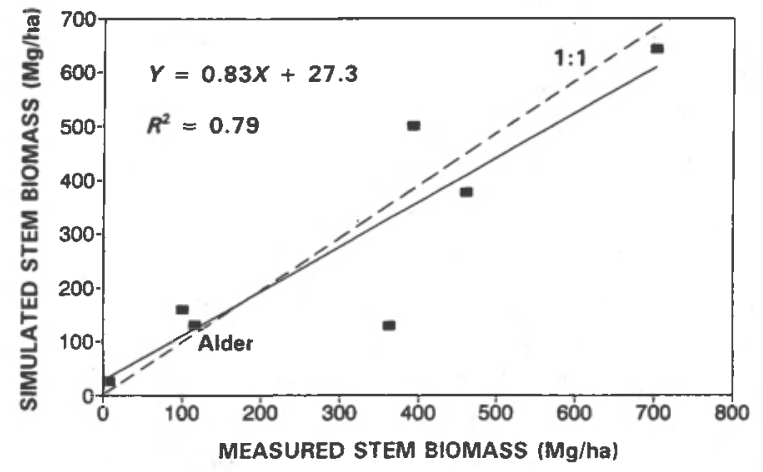

FIG. 5. FOREST-BGC validation at the seven OTTER sites: current stem biomass compared to stem biomass simulated at $100 \mathrm{yr}$. The model was initiated with current LAI but with stem biomass defined as $10 \%$ of the current value, to simulate growth of the stands from a sapling condition to the present time.

period of water stress better represents the cumulative effect of water limitation on physiological processes (Myers 1988). The Scio site was under water stress from yearday 180 to 290 ; however, due to the mild winter climate of Scio, by yearday $180,15 \mathrm{Mg}$ of the annual total of $22 \mathrm{Mg}$ of carbon had already been fixed. Consequently the short, intense summer water stress at Scio is only a brief interruption to a mild, nearly 12-mo photosynthetic season.

Simulation of LAI is a critical test of our understanding of how climate controls vegetation development and critical canopy processes. The primary climatic control of LAI is assumed to be water balance (Grier and Running 1977, Woodward 1987). Given the central importance of water balance for predicting LAI, the lack of useable soil water capacity data was unfortunate. However, this is more indicative of the global situation, where SWC is not readily available. FOREST-BGC does an annual optimization of the multiple controls of carbon, water, and nitrogen availability for leaf tissue growth, then defines LAI as a function of the most limiting resource. The test of predicted against observed equilibrium LAI (Fig. 4) shows one conspicuous outlier, the Scio site, with LAI predicted at 4.7 and measured at 8.6. The problems of inaccurately simulated water stress at Scio have already been discussed. FOREST-BGC also simulated a rather low LAI at Scio because of nitrogen limitations to tissue growth; LAI simulated for the fertilized Scio site was 6.6, compared to the observed 8.6.

FOREST-BGC simulated development of the OTTER stands over $100 \mathrm{yr}$, beginning from a point of canopy closure with $\mathrm{LAI}$ at climatic equilibrium, and with small stem biomass equivalent to a sapling stand. The simulation results at year 100 represent a mature, unperturbed forest stand. All of the OTTER sites supported mature, fully stocked forest stands except Metolius, which had been partially cut. To represent an uncut stand at Metolius, stem biomass field measure- ments were replaced with data from Gholz (1982); the comparison between predicted and observed stem biomass is shown in Fig. 5. The Alder stem biomass peaked at $132 \mathrm{Mg} / \mathrm{ha}$ in year 30 , and mortality and respiration losses reduced it to $103 \mathrm{Mg} /$ ha by year 100 (Fig. 6). These carbon cycle simulations appear to realistically represent the short life-cycle dynamics of Alder. Simulations of the conifer stands all showed stem biomass to be still slowly accumulating or stable at year 100 (Fig. 6). Because mortality is not mechanistically modeled, simulations beyond $\approx 100 \mathrm{yr}$ would not be expected to match real stand biomass dynamics well. A new version of FOREST-BGC is being developed that mechanistically simulates stand recruitment and mortality, to provide a more realistic forest stand simulator.

\section{Nitrogen cycle simulations}

The FOREST-BGC model simulates a simple annual nitrogen budget, which then controls aboveground/belowground carbon allocation and LAI development of the stand. At each annual iteration, nitrogen from litter and soil decomposition, leaf retranslocation, and external atmospheric inputs is added to an available $\mathrm{N}$ compartment, then the $\mathrm{N}$ is stoichiometrically added to new leaf, stem, and root growth. These nitrogen budget computations are not as mechanistic as those done in the GEM model of Rastetter et al. (1991). Nonetheless, FOREST-BGC leaf nitrogen concentrations were well correlated with observations of both the fertilized and control stands in the OTTER project (Fig. 7). Again, the deciduous Alder stand was the conspicuous outlier.

To briefly illustrate the influence of nitrogen availability on the carbon cycle simulations, the 100-yr simulations for the control and fertilized Metolius site are

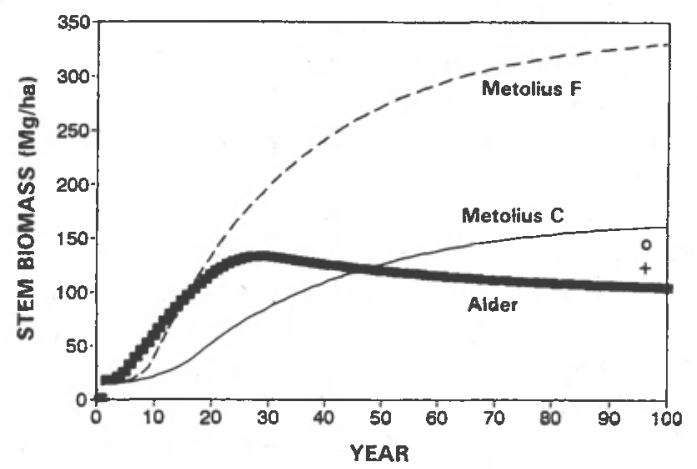

FIG. 6. One-hundred-year simulation of stem biomass development for the Alder site, and the Metolius control and fertilized sites. The rapid early development in biomass for the alder stand at $<30 \mathrm{yr}$ is commonly observed in the field. Fertilization on the Metolius site improved the stem biomass production considerably, despite being a dry site of only 54 $\mathrm{cm}$ annual precipitation, which resulted in no change in simulated LAI of 2.8 from the control simulation. $+=$ the measured stem biomass at the Alder site, $\mathrm{O}=$ the stem biomass measured for the Metolius control by Gholz (1982). 


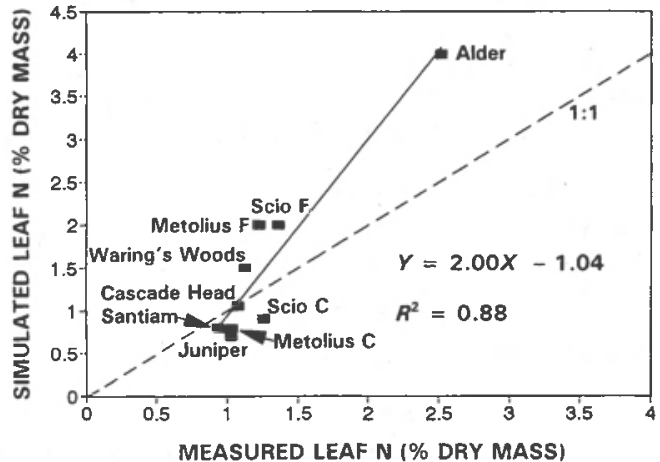

FIG. 7. The leaf nitrogen concentration measured in March 1990 by Matson et al. (1994 [this issue]) compared to the simulated leaf nitrogen concentration at the end of a $100-\mathrm{yr}$ simulation.

presented in Fig. 7. This site is very dry and highly water limited during the growing season (Fig. 2). Consequently, FOREST-BGC simulated no increase in LAI of the fertilized stand (not shown), but stem biomass production increased due to higher photosynthetic capacity defined by leaf nitrogen concentrations (Fig. 7) and higher aboveground/belowground carbon partitioning. Although we have no field data to validate this simulation, these responses reasonably represent responses found in forest fertilization trials done in arid climate forests (Gower et al. 1992).

\section{CONCLUSIONS}

It is extremely difficult and costly to obtain rigorous parameterization and complete validation data for complex ecosystem models. The OTTER project initially planned to collect validation data for all variables listed at the beginning of this paper. Realistically, the project budget should have been five times greater to collect the required data accurately. Regional or multisite field studies should concentrate on critical integrating system variables that can be measured reasonably accurately and repetitively; carbon cycle variables such as ANPP, LAI, and canopy litterfall seem best. Simple structural controls of carbon cycle dynamics such as specific leaf area and leaf turnover rate need to be collected (Gower and Richards 1990). Snowmelt dynamics and bulk soil water depletion or total surface resistance are the most stable hydrologic measurements. Total canopy $\mathrm{N}$ and litterfall $\mathrm{N}$ provide the most measurable simple assessment of nitrogen cycle dynamics.

Ecosystem gas exchange processes, relying on expensive, erratic cuvette measurements, are probably the worst variables for validation. Yoder (1992) attempted to measure $A_{\max }$, or the photosynthetic capacity, a key system flux capacity, and was unsuccessful in getting dependable data for even one site, not to mention the entire transect. Simple carbon budget estimates, as suggested by Ryan (1991), may provide a practical alternative.
Plant-available soil water-holding capacity sounds like a straightforward variable, but in fact is nearly impossible to accurately define ecologically for trees, because the rooting distribution, often in highly irregular soils, must be known. Alternative means of defining soil water storage need to be developed.

As maps and simulations of ecosystem processes at regional scales are produced, validation problems become even larger, and there are far fewer field-measurable system variables to choose from (Burke et al. 1990). Simple spatially integrated variables, such as watershed stream runoff, regionally observed snowmelt, regional drought monitors (Nemani et al. 1993), atmospheric $\mathrm{CO}_{2}$ trends (Keeling et al. 1989), and satellite Vegetation Index dynamics (Burke et al. 1990), may be our only choices for regional validations. At these larger scales validation data for gas exchange processes will require micrometeorological (Baldocchi et al. 1988) and aircraft-based measurements (Matson and Harriss 1988).

The final goal of creating process-based global ecological models is attainable by implementing tested models at progressively larger scales. However, the progressive extrapolation of process-based ecosystem models requires a changing array of model drivers and validation procedures. LAI can be measured leaf by leaf by direct sampling, by stem allometry for a single tree canopy, by optical transmission for a stand of trees, and finally by satellite for whole regions. Confidence (if not formal validation) developed for a model logic at one scale is not lost as that model is implemented at a larger scale if the logic and model structure remains intact and only key variables are defined in a new way. The overriding system limitations provided by topdown biophysical variables such as APAR (absorbed photosynthetically active radiation), precipitation, and latent energy availability can constrain the mechanistic simulations to reality at scales where direct process measurements are impossible.

\section{ACKNOWLEDGMENTS}

Primary funding for this project was from NASA grant number NAGW-1892 and NASA grant number NAGW-952. Richard H. Waring and David L. Peterson took the extra responsibility of coordinating the project. I thank Peter Thornton for assisting in simulations and Joe Glassy for building the climate files. Tom Gower and Lars Pierce reviewed early versions of the manuscript.

\section{LITERATURE CrTED}

Ågren, G. I., R. E. McMurtrie, W. J. Parton, J. Pastor, and H. H. Shugart. 1991. State-of-the-art of models of production-decomposition linkages in conifer and grassland ecosystems. Ecological Applications 1:118-138.

Avissar, R., and M. M. Verstraete. 1990. The representation of continental surface processes in atmospheric models. Reviews of Geophysics 28:35-52.

Baldocchi, D. D., B. B. Hicks, and T. P. Meyers. 1988. Measuring biosphere-atmosphere exchanges of biologically related gases with micrometeorological methods. Ecology 69: 1331-1340.

Band, L. E., P. Patterson, R. R. Nemani, and S. W. Running. 
1993. Forest ecosystem processes at the watershed scale: incorporating hillslope hydrology. Agricultural and Forest Meteorology 63:93-126.

Bonan, G. B. 1991. Atmosphere-biosphere exchange of carbon dioxide in boreal forests. Journal of Geophysical Research 96:7301-7312.

Burke, 1. C., D. S. Schimel, C. M. Yonker, W. J. Parton, L. A. Joyce, and W. K. Lauenroth. 1990. Regional modeling of grassland biogeochemistry using GIS. Landscape Ecology 4:45-54.

Gholz, H. 1982. Environmental limits on aboveground net primary production, leaf area, and biomass in vegetation zones of the Pacific Northwest. Ecology 63:469-481.

Gower, S. T., and J. H. Richards. 1990. Larches: deciduous conifers in an evergreen world. BioScience 40:818-826.

Gower, S. T., K. A. Vogt, and C. C. Grier. 1992. Carbon dynamics of Rocky Mountain Douglas-fir: influence of water and nutrient availability. Ecological Monographs 62: 43-65.

Grier, C. C., and S. W. Running. 1977. Leaf area of mature northwestern coniferous forests: relation to site water balance. Ecology 58:893-899.

Hinckley, T. M., and R. Ceulemans. 1989. Current focuses in woody plant water relations and drought resistance. Annals of Science in Forestry 46s:317s-324s.

Hunt, E. R., Jr., F. C. Martin, and S. W. Running. 1991. Simulating the effects of climatic variation on stem carbon accumulation of a ponderosa pine stand: comparison with annual growth increment data. Tree Physiology 9:161-172.

Jarvis, P. G. 1981. Production efficiency of coniferous forest in the UK. Pages 81-107 in C. B. Johnson, editor. Physiological processes limiting plant productivity. Butterworths, London, England.

Keeling, C. D., R. B. Bacastow, A. F. Carter, S. C. Piper, T. P. Whorf, M. Hiemann, W. G. Mook, and H. Roeloffzen. 1989. A three-dimensional model of $\mathrm{CO}_{2}$ transport based on observed winds. I. Analysis of observational data. Pages 165-234 in Monograph 55. American Geophysical Union, Washington, D.C., USA.

Knight, D. H., T. J. Fahey, and S. W. Running. 1985. Factors affecting water and nutrient outflow from lodgepole pine forests in Wyoming. Ecological Monographs 55:2948.

Knight, D. H., T. J. Fahey, S. W. Running, A. T. Harrison, and L. L. Wallace. 1981. Transpiration from 100-yearold lodgepole pine forests estimated with whole-tree potometers. Ecology 62:717-726.

Korol, R. L., S. W. Running, K. S. Milner, and E. R. Hunt, Jr. 1991. Testing a mechanistic carbon balance model against observed tree growth. Canadian Journal of Forest Research 21:1098-1105.

Matson, P. A., and R. C. Harriss. 1988. Prospects for aircraft-based gas exchange measurements in ecosystem studies. Ecology 69:1318-1325.

Matson, P. A., L. Johnson, C. Billow, J. Miller, and R. Pu. 1994. Seasonal patterns and remote spectral estimation of canopy chemistry across the Oregon transect. Ecological Applications 4:280-298.

McLeod, S., and S. W. Running. 1988. Comparing site quality indices and productivity of ponderosa pine stands in western Montana. Canadian Journal of Forestry Research 18:346-352.

Meehl, G. A., and W. M. Washington. 1988. A comparison of soil-moisture sensitivity in two global climate models. Journal of the Atmospheric Sciences 45:1476-1492.

Myers, B. J. 1988. Water stress integral-a link between short-term stress and long-term growth. Tree Physiology 4: 315-323.

Nadelhoffer, K. J., and J. W. Raich. 1992. Fine root pro- duction estimates and belowground carbon allocation in forest ecosystems. Ecology 73:1139-1147.

Nemani, R. R., L. L. Pierce, S. W. Running, and S. N. Goward. 1993. Developing satellite derived estimates of surface moisture status. Journal of Applied Meteorology 32: 548-557.

Nemani, R. R., and S. W. Running. 1989. Testing a theoretical climate-soil-leaf area hydrologic equilibrium of forests using satellite data and ecosystem simulation. Agricultural and Forest Meteorology 44:245-260.

Ojima, D., editor. Modeling the earth system. University Corporation for Atmospheric Research. Boulder, Colorado, USA.

Parton, W. J., D. S. Schimel, C. V. Cole, and D. S. Ojima. 1987. Analysis of factors controlling soil organic matter levels in Great Plains grasslands. Soil Science Society of America Journal 51:1173-1179.

Peterson, D. L., and R. H. Waring. 1994. Overview of the Oregon Transect Ecosystem Research project. Ecological Applications 4:211-225.

Prescott, C. E., J. P. Corbin, and D. Parkinson. 1989. Input, accumulation and residence times of carbon, nitrogen and phosphorus in four Rocky Mountain coniferous forests. Canadian Journal of Forest Research 19:489-498.

Rastetter, E. B., M. G. Ryan, G. R. Shaver, J. M. Melillo, K. J. Nadelhoffer, J. E. Hobbie, and J. D. Aber. 1991. A general biogeochemical model describing the responses of $\mathrm{C}$ and $\mathrm{N}$ cycles in terrestrial ecosystems to changes in $\mathrm{CO}_{2}$, climate and $\mathrm{N}$ deposition. Tree Physiology 9:101-126.

Running, S. W., and J. C. Coughlan. 1988. A general model of forest ecosystem processes for regional applications. I. Hydrologic balance, canopy gas exchange and primary production processes. Ecological Modelling 42:125-154.

Running, S. W., and S. T. Gower. 1991. FOREST-BGC, a general model of forest ecosystem processes for regional applications. II. Dynamic carbon allocation and nitrogen budgets. Tree Physiology 9:147-160.

Runyon, J., R. H. Waring, S. N. Goward, and J. M. Welles. 1994. Environmental limits on net primary production and light-use efficiency across the Oregon transect. Ecological Applications 4:226-237.

Ryan, M. G. 1991. A simple method for estimating gross carbon budgets for vegetation in forest ecosystems. Tree Physiology 9:255-266.

Schimel, D. S., T. G. F. Kittel, and W. J. Parton. 1991. Terrestrial biogeochemical cycles: global interactions with the atmosphere and hydrology. Tellus 43AB:188-203.

Vitousek, P. M., T. Fahey, D. W. Johnson, and M. J. Swift. 1988. Element interactions in forest ecosystems: succession, allometry and input-output budgets. Biogeochemistry 5:7-34.

Vogt, K. 1991. Carbon budgets of temperate forest ecosystems. Tree Physiology 9:69-86.

Vogt, K. A., C. C. Grier, and D. J. Vogt. 1986. Production, turnover, and nutrient dynamics of above- and belowground detritus of world forests. Advances in Ecological Research 15:303-377.

Waring, R. H., and W. H. Schlesinger. 1985. Forest ecosystems. Academic Press, New York, New York, USA.

Woodward, F. I. 1987. Climate and plant distribution. Cambridge University Press, Cambridge, England.

Yoder, B. 1992. Photosynthesis of conifers: influential factors and potential for remote sensing. Dissertation. Oregon State University, Corvallis, Oregon, USA.

Zobel, D. B., W. A. McKee, G. M. Hawk, and C. T. Dyrness. 1976. Relationships of environment to composition, structure and diversity of forest communities of the central western Cascades of Oregon. Ecological Monographs 46:135156. 